\title{
Fransız Milli Kütüphanesinde Bulunan 482 Envanter Numaralı Mushafın Tezyini Açıdan Değerlendirilmesi
}

\author{
Çiğdem ÖNKOL ERTUNÇ ${ }^{1}$, İclal BEŞTAV ${ }^{2}$ \\ ${ }^{1}$ Dr. Öğr. Üyesi, Necmettin Erbakan Üniversitesi, Güzel Sanatlar Fakütlesi, Geleneksel Türk Sanatları Bölümü, Konya, \\ Türkiye, certunc@erbakan.edu.tr \\ ${ }^{2}$ Necmettin Erbakan Üniversitesi, Sosyal Bilimler Enstitüsü, Geleneksel Türk Sanatları Anasanat Dalı, Yüksek Lisans \\ Öğrencisi, Konya, Türkiye, bestaviclal@gmail.com
}

\begin{tabular}{|c|c|}
\hline Makale Bilgileri & ÖZ \\
\hline Makale Geçmişi & Geleneksel Türk Süsleme Sanatlarımız tarihimiz boyunca gelişme göstererek günümüze kadar gelmiş \\
\hline $\begin{array}{l}\text { Geliş: } 19.10 .2020 \\
\text { Kabul: } 24.11 .2020 \\
\text { Yayın: } 25.12 .2020\end{array}$ & $\begin{array}{l}\text { ve geçmişimizi bu günümüze bağlamıştır. El yazması eserlerin bilgi birikimini aktarması açısından } \\
\text { öneminin yanı sıra, tezyini açıdan da tarihimize ışık tutmaktadır. Bu eserler kültür ve medeniyetimizin } \\
\text { anlaşılması açısından en önemli tarihi hazinelerimizdendir. Tezhipli eserler hem dönemleri hem de } \\
\text { içeriklerinde bulunan bilgiler sayesinde geçmişimize } 1 \text { şı tutmaktadır. Bu esereler yazılıp }\end{array}$ \\
\hline $\begin{array}{l}\text { Anahtar Kelimeler: } \\
\text { Geleneksel }\end{array}$ & $\begin{array}{l}\text { süslendikleri dönemin sanat anlayışını, üslubunu ve farklılıklarını gösterir. Tarihimize dair tezyini } \\
\text { gelişmeleri takip edebilmemiz, öğrenebilmemiz ve değerlendirip inceleyebilmemiz açısından tezhipli }\end{array}$ \\
\hline El yazmasi & eserler çok önemlidir. El yazması eserlerin korunması, daha iyi anlaşılması ve gelecek nesillere \\
\hline Tezyinat & aktarılması amacıyla 'Fransız Milli Kütüphanesi’nde Bulunan '482' Envanter Numarası ile Kayıtlı \\
\hline Tezhip & Kur-ân-1 Kerim' in tezyini özelliklerinin değerlendirilmesi çalışmanın konusu olarak belirlenmiştir. \\
\hline Motif. & $\begin{array}{l}\text { Bozulmadan korunması sağlanmış tezhipli bölümler desen, motif, renk, tasarım bütünlüğ̈̈, yazı } \\
\text { mürekkebi ve teknik bakımdan incelenmiştir. Mushaf'ın yazıldığı dönem tezyinatı hakkında bilgi } \\
\text { verilmiştir. Çalışma görsel malzemeler ve çizimlerle desteklenmiştir. }\end{array}$ \\
\hline
\end{tabular}

\section{Evaluation In Terms Of Decoration On Inventory Number 482 In The French National Library}

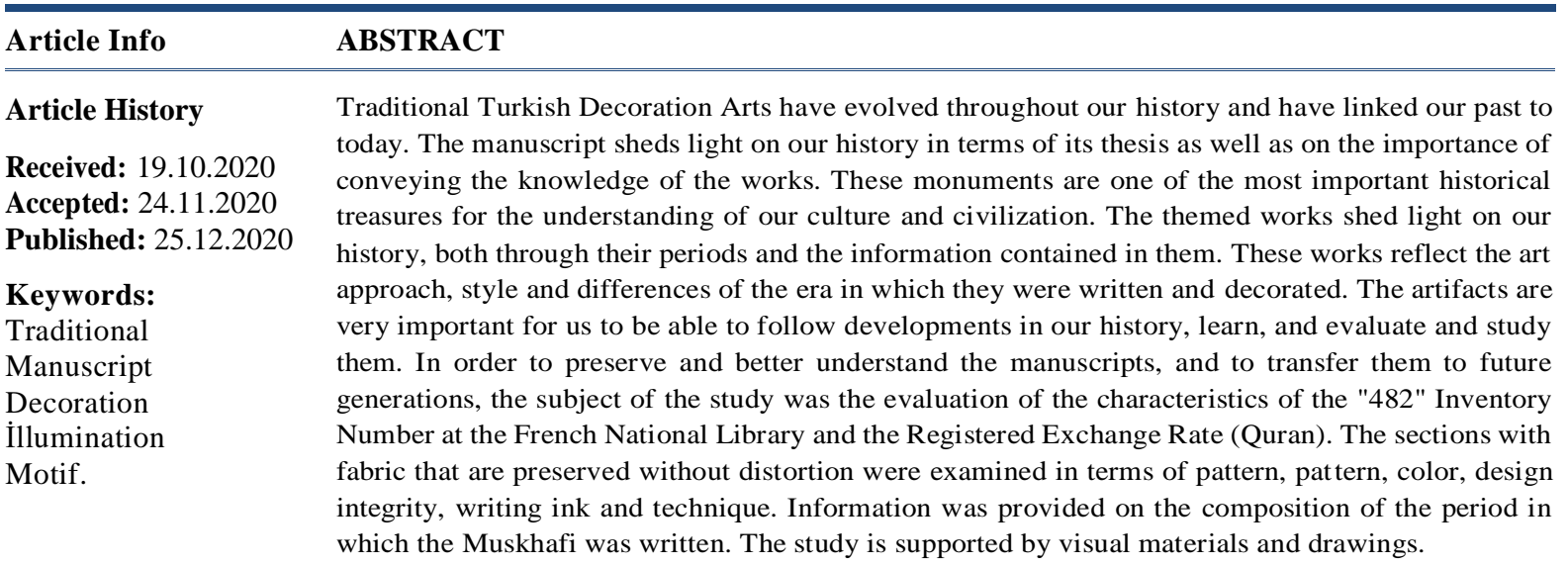

Atıf/Citation: Ertunç., Ö, Ç. \& Beştav., İ. (2020). Fransız Milli Kütüphanesinde Bulunan 482 Envanter Numaralı Mushafın Tezyini Açıdan Değerlendirilmesi, Konya Sanat Dergisi, 3, 49-63. 


\section{GİRIŞ}

İnsanlık tarihinin ve İslâm inancının en önemli birikimi yazıdır. Bilgiler, birikimler, edebi eserler, ilim ve fen bilimleri adına oluşturulan bütün kayıtlar yazı sayesinde tarih içerisinde sürekliliğini sağlamıştır. İlim ve edebi eserleri muhteviyatında bulunduran yazma eserler, kütüphanelerde kayıt altına alınmış ve arşivlenmiştir.

Paris'te bulunan Fransız Milli Kütüphanesi, dünyanın dört bir yanından toplayıp kayıt altına aldığı yazma eserleri insanlığın hizmetine sunmaktadır. Fransa'nın dünyanın en büyük imparatorluklarından biri olması yeryüzündeki bütün toplumlara ve milletlere ait belge toplaması açısından avantaj sağlamıştır. Fransız milli kütüphanesinin amacı eserleri düzenleyip korumak ve görmek isteyen kişilere fayda sağlamaktır. Çok köklü bir tarihe ve kültüre sahip olan Türkiye, geçmişten günümüze kadar sınırları içinde meydana getirilen sayısız yazma eserle çok ciddi bir birikime sahiptir. Fransız milli kütüphane bu eserlerden iki binin üstünde el yazmasına ve sekizyüze yakın kitaba sahiptir.

Kütüphanenin dijital kayıtlarına yine aynı kütüphanenin oluşturduğu 'Gallica Digital Library'den ulaşmak mümkündür. Kütüphanenin dijital arşivinde mevcut olan 482 numaralı Mushaf, ketebe sayfası bulunmayan eserin kütüphane kayıtlarında 16. yüzyıla tarihlendirilmiştir.

Çalışmamızın amacı Mushaf'ı form, teknik, desen ve renk açısından inceleyip yapılan değerlendirmeler ve analizlerin sonucunda, 16.yy. Osmanlı tezyinatı Mushaf tezhipleri özelliklerine uygun olup olmadığını araştırmaktır. Bu karşılaştırmalar neticesinde mushafın tezyini özellikleri bu yüzyılda yapılmış tespit edilen farklı Mushafların tezyini özellikleri mukayeseli olarak analiz edilecektir.

\section{XVI. Yüzyıl Mushaf Tezyinati ve Tezhip Sanati}

Tezhip sanatı tezyinatın ve bezeme sanatının kağıt üzerine yapılan şeklidir. Türklerin İslamiyetin kabulüyle yeni ve farklı bir şekle geçiş yapan tezhip, hüsn-i hat ve minyatür sanatlarıyla bir arada kullanılmıştır Bunun yanı sıra tezhip sanatının tarihi, hat sanatının tarihiyle birlikte başlangıç göstermiş ve gelişimini hat sanatıyla paralel olarak hızlandırmıştır. Tezhip kelime manası olarak Arapça' da "altın" anlamına gelen "zehep" kökünden türemiştir (Özönder, 2006: 198). Ana malzeme olarak kullanılan altının yanı sıra lapist lazuli (bedahşi lacivert), bordo, turkuaz ve limon küfü gibi klasik renklerde kullanılmıştır.

Mushaf terimi zamanla Kur'ân- 1 Kerimlere verilen genel bir isim olarak karşımıza çıkar. Sözlükte "bir araya getirilip bağlanmış yazılı sayfalar" diye tanımlanan Mushaf, Kur'ân'ın sahifelerini toplayan cilde verilen isimdir. Hz. Ebubekir döneminde iki kapak arasına toplanan Kur'ân-1 Kerime "Mushaf" ad1 verilmiştir (Baysal, 2010: 366). Mushaf yazma geleneği, İslam medeniyetinde önemli yer tutar. Mushaf'ın meydana getirilmesinde gerek hat gerekse tezhip açısından oldukça özen gösterilmiştir. Mushaflar tarih boyunca sanatında mahir hattatlar tarafından istinsah edilmiş, müzehhipler tarafından tezhiplenmiş, mücellitler tarafindan da ciltlenmiştir. Bundan dolayı Mushaflar sanatsal ve estetik değeri ile de dikkat çeker. Mushaf yazımına fazla özen gösteren üstatlar, baş kısmının daha güzel olması için çok defa Kur'an'ı onuncu cüzden başlayarak sonuna kadar yazar, ardından başa döner ve onuncu cüze kadar yazarlardı. Kur'an metni yazıldıktan sonra daha ince bir kalemle hareke, kırmızı mürekkeple secâvend işaretleri konur ve sayfalar tezhip edilirdi (Serin, 2006: 252). Kutsal kitap olarak değerlendirildiği için özenle muhafaza edilmiş, bunun için özel kutular bile imal edilmiştir. Başta camiler olmak üzere hemen her evde en az bir tane bulunan Mushaflar çok sayıda üretilmiştir. Hz. Osman döneminden günümüze farklı dönemlerde istinsah edilen Mushaflar gerek yurt içinde gerekse yurt dışında pek çok müze, kütüphane ve koleksiyonda itina ile muhafaza edilmektedirler.

XV. yüzyıl Osmanlı tezhip sanatında, bir ekol niteliğinde olan Fatih döneminde sanat ve sanatçıya ayr1 özen gösterilmiştir (Küpeli, 2009: 321). Fatih'in kitaba, sanata ve ilme çok önem vermiş, kendi özel 
kütüphanesi için çok sayıda kitap istinsah ettirmiş dolayısıyla bu dönemde yapılan kültür faaliyetleri önemli ölçüde hızlanmıştır. (Aşıc1, 2009: 301). Fatih’ten sonra şehzadelik yıllarında Hattat Şeyh Hamdullah'tan ders almış olan Bayezid tahta geçince hocasını saraya alarak Edirne'de bir meşk hane tahsis etmiştir (Serin, 2003: 90; Küpeli, 2009: 328). Bunun yanısıra Topkapı Sarayında bir nakkaşhanenin oluşmasını sağlamıştır. Nakkaşhanenin çalışma disiplinini Ehl-i Hıref kayıtlarından anlamak mümkün olup teşkilat bünyesinde çalışan sanatçı ve sanatçı gruplarından onların aldıkları ücrete kadar tutulan kayıtlar dönemin sanatçı kimliklerini de ayrıntılı şekilde ortaya koymaktadır (Aşıcı, 2009: 307).

$\mathrm{Bu}$ dönemde stilize edilerek sadeleştirilmiş motifler asli karakterlerinden oldukça uzaklaştırılmıştır. Hatâyiler, rûmîler, bulutlar, altın ve lacivertin muhteşem uyumu ile ihtişam kazanmıştır. Dönemin önemli özelliklerinden biri de renk kompozisyonlarıdır. Bu dönemde altın bol miktarda kullanılmıştır. Devrin Kur'ân-1 Kerim tezhipleri hattıyla uyumlu zarafette ve ölçülü kullanılması ile dikkat çeker. Süsleme sanatlarının en parlak dönemi olan XVI. yüzyılda Mushaf tezyinatına özellikle önem verilmiştir. Osmanlı tezhibinin çok farklı şekillerde kompozisyonlar içeren en önemli eseri olan, Ahmet Karahisâri’ nin yazdığı Kur'ân-1 Kerim de bu dönemde tezhiplenmiştir. Her bir sayfası tezhipli olan Kur'ân-1 Kerim dönemin zarafetini, ustalı̆̆ını ve birikimini gösteren önemli bir kaynaktır.

Bayezid devri Kur'an tezhiplerinde çeşitli ana şemalar uygulanmıştır. Özellikle başlangıç levhalarındaki kompozisyon düzenlemelerinde sınırlandırmayan desenlerden alınan kesitler kullanılmıştır. Tezhipli sayfalar levhalar, bordürler ve tığlarla zenginleştirilmiştir. Dolgu motifleri rumîler, hatayîler, tepelik ve orta bağlar ve yeni bir motif olarak yaygın bir şekilde kullanılan çin bulutlarıdır. Rumîler incelmiş ve çeşitlilik kazanmıştır. Motifler daha ince ve zarif şeklini almıştır.

Mushaf yazma ve tezhipleme geleneği klasik dönem diye adlandırdığımız XVI. yüzyılda zirveye ulaşmıştır. $\mathrm{Bu}$ dönemde Osmanlı hinterlandındaki kültürlerin katkısıyla farklı tasarımlara sahip müzehhep Mushaflar da üretilmiştir. Devrin nakkaşhanesinin üslubunu yansıtan Mushafların tezhipleri hatâyiler, rûmîler, bulutlar, altın ve lacivertin muhteşem uyumu ile ihtişam kazanmıştır (Baysal \& Sayın, 2019: 43).

1520-1566 yı1ları arasında yarım yüzyıla yakın bir dönem saltanat süren Kanûnî Sultan Süleyman yılları arasında da zengin bir tezyin anlayışı ve sanatlarların himayesi ve teşvikiyle hareketlenmiş önemli bir dönemdir. Bu dönemde faaliyet gösteren saray nakkaşlanesi geniş bir sanatçı kadrosu ile tüm kitap sanatları dallarında, çini, ahşap, kalem işi, seramik uygulamalarında tasarımlar hazırlayan bir sanat merkezidir (Mesara, 2009: 361).

Hasan b. Abdullah, Bayram b. Derviş, Pir Ahmed b. İskender gibi nakkaşlar, Hatayiler ve Rûmîlerin, Goncagüllerin çıplak gözle zor seçilecek kadar küçük ama bir o derecede ince ve zarif çizilmiş genel tasarımlarının olduğu tezyini eserler vermişlerdir. Müzehhiplerin bu hüner ve maharetleri bu dönemin tezhip anlayışının gelişmesinde önemli rol oynamıştır. Sarayın baş nakkaşı Şahkulu, Kalemi Siyah tekniği hançeri yapraklar arasına efsanevi figürler ve hatayiler ile farklı kompozisyon teknikleri ortaya koymuştur. Kanuni Sultan Süleyman döneminde Nakkaş Karamemi, nakkāş Hasan, nakkāş Mustafâ, nakkāş Ca'fer ve nakkāş Alî Çelebi, Şah Mehmed, Mehmed Eyyubi, Ali b. Bayram, Abdülgani, Evrenos, İsmail ve Hacı Abdi isimli sanatkarlar çok sayıda Mushaf ve yazma eser tezhiplemişlerdir. Dönemin temel tezyini üslubunun yansıtıldığı nadide eserler süslemenin yer aldığı her alanda kullanılmıştır. Saraylar, camiler saz yolu ve natüralist üslûplardaki çini ve kalemişleri ile donatılmıştır. Osmanlıya özgü bu yeni tezyini akım klasik motif birikimini zenginleştirerek özellikle Karamemi'nin kitap sanatlarında enfes farklı üslupta eserler vermesine neden olmuştur. Karamemi'nin nakkaşhanesi tarafından tezhiplenen ve Kanuni'ye takdim edilen "Muhibbî Dîvânı" tezyinat tarihinin önemli yapı taşlarından biridir. Gerek klasik gerekse metin içinde bulunan diğer tezyini alanlarda 
kullanılan natürülist üsluptaki desenlerle eşsiz bir tezyinat üslubu sergileyen eserin farklı nakkaşlar ile birlikte tezhiplendiği tezhipli alanlarında bulunan işçilik farkından anlaşılmaktadır. Yine Kanuni dönemine atfedilen çift tahrir tekniğinin de kullanımıyla Dîvân'ın tüm sayfaları adeta bir çiçek bahçesi zerafetinde tezyin edilmiştir.

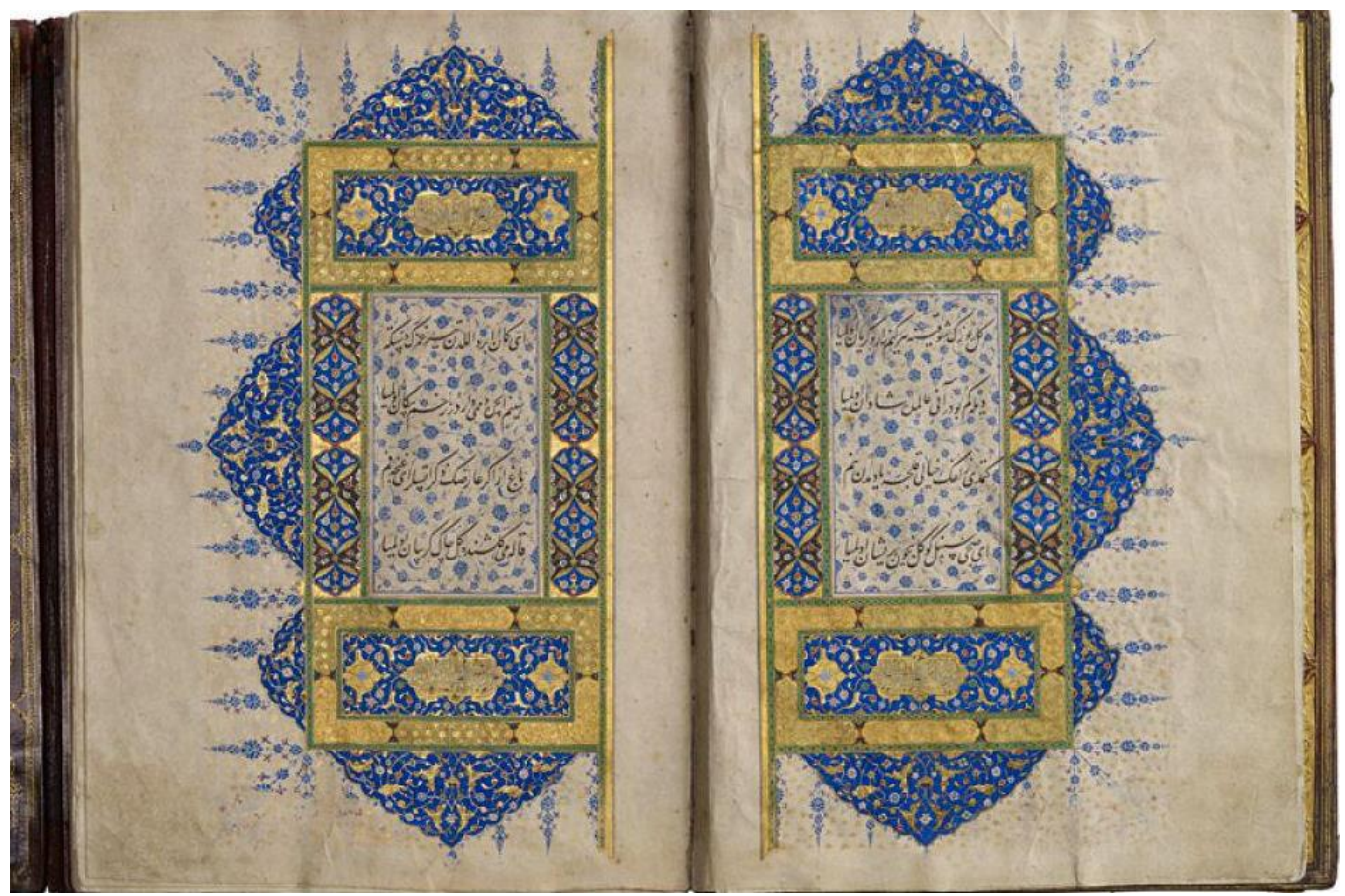

Resim 1: Muhibbi Divanı MKG Sanat ve Endüstri Müzesi 1886.168 (http://islamicart.museumwnf.org/database_item.php?id=object;EPM;de;Mus21;5;en. Erişim Tarihi: 02/11/2020)
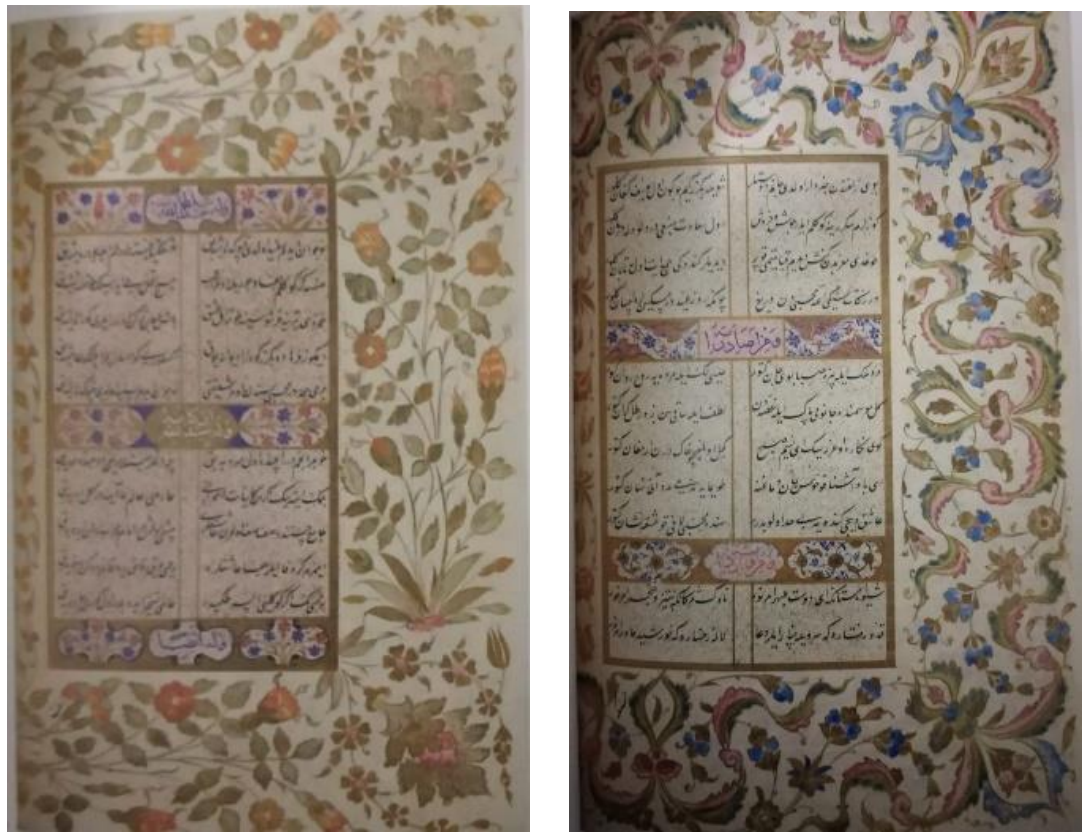

Resim 2: Muhibbi Dîvânı Sayfa Düzeni Örnekleri (Atasoy, 2016, 179b, 126b) 


\section{482 Nolu Mushafta Bulunan Tezhipli Bölümler}

\subsection{Serlevha}

Türkçe sözlükteki karşılığ1 "'Baş" olan Farsça "'Ser" kelimesi Arapça “Levha" kelimesi ile birleşerek bir yazının başlığı anlamını taşımaktadır. Mushaflarda genellikle zahriye sayfasından sonraki iki sayfa ser levha sayfası olarak düzenlenir. İlk sayfada Fatiha Sûresi, ikinci sayfada ise Bakara Sûresinin ilk ayetleri yazılıdır ve ayetlerin kenarları bezeme açısından oldukça zengin tutulur. Zahriye sayfasından sonra en yoğun süsleme ser levha sayfalarında görülür (Hatipoğlu, 2014: 150). Mushaflardaki serlevhalar eserin tamamındaki bütünlüğü ve uyumu sağlamak maksadıyla eserin diğer tezyinatlı kısımları ile desen, renk ve motif açısından uyumludur (Resim 1). Karşılıklı ve çift şeklinde düzenlenen ser levha sayfaları Mushaf' taki bezemelerin bütünlüğünü korumak maksadıyla renk, desen ve motif açısından zahriye sayfasıyla uyumlu olmalıdır (Duran, 2012: 63; Baysal, 2010: 372).
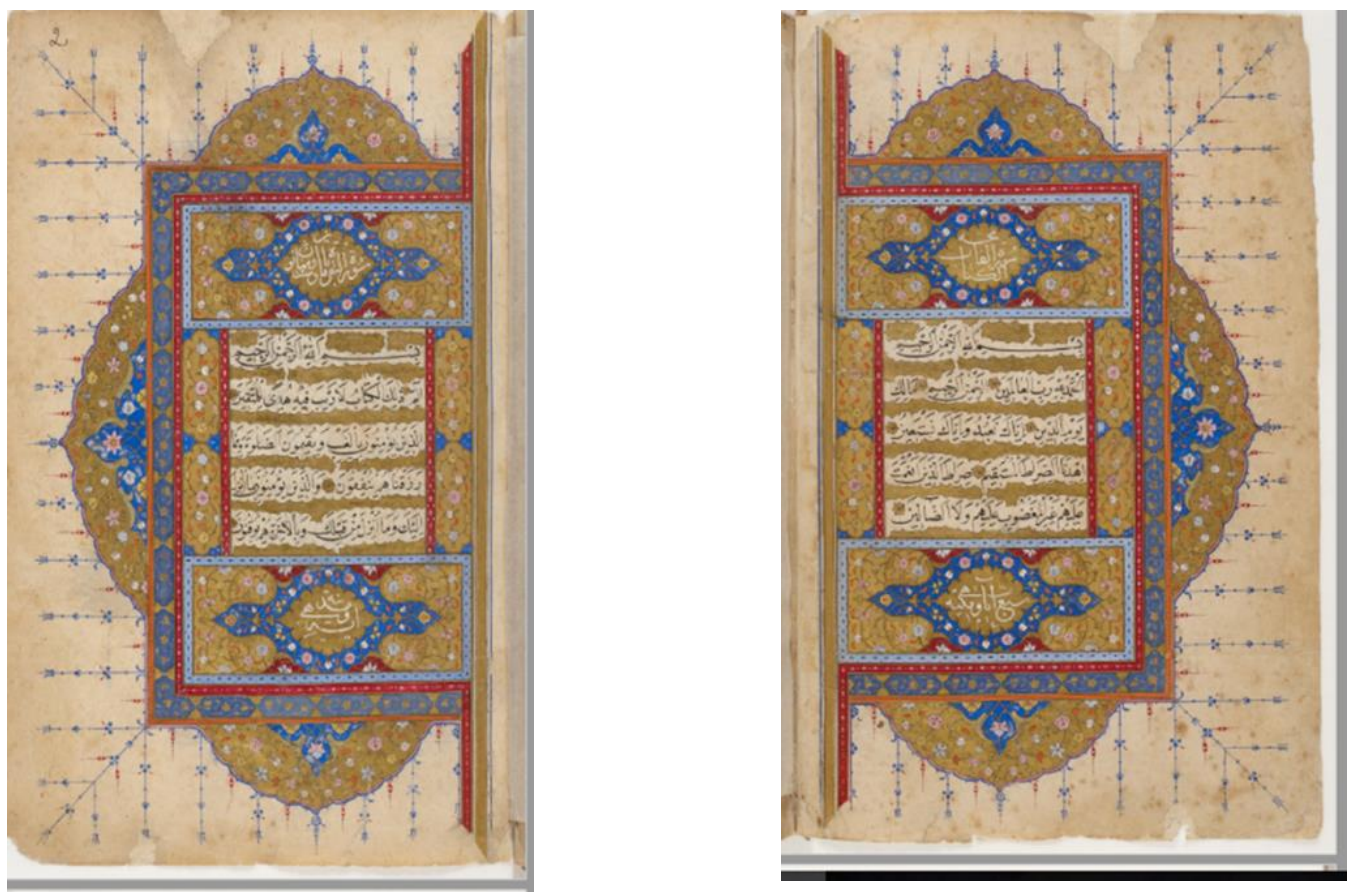

Resim 3: Serlevha Genel Görünümü
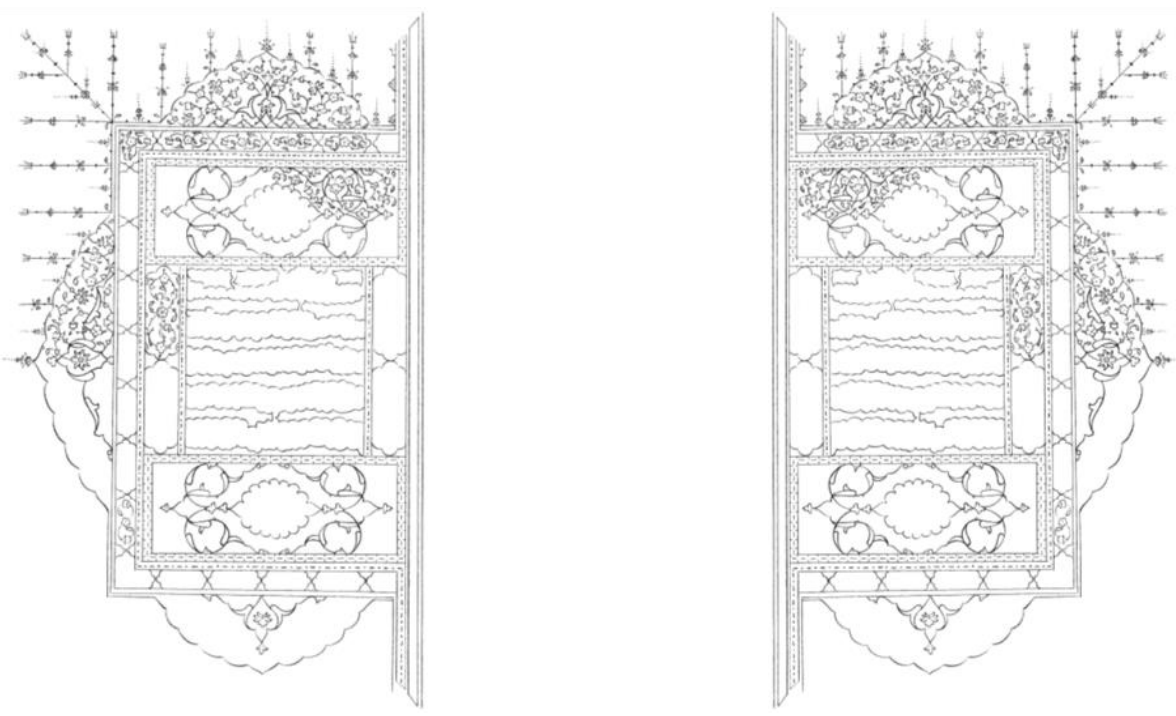

Resim 4: Serlevha Çizim 
İncelemeye aldığımız Mushaf’ta, serlevha kısmı dikdörtgen forma düzenlenmiştir. Dikdörtgenin iç kısmı üç bölümdür. Bu alanın dış kısmı ise üstte, altta ve yanda bulunan dendanlı yarım şemselerle zenginleştirilmiştir. Dikdörtgen alanın iç kısmı üç bölümden oluşmaktadır. Yukarıda ve aşağıdaki dikdörtgen formlar, ortada yatay şemse formu ve köşelerde rûmî deseni ile paftalanmış köşebentler yer alır. Ortadaki yatay şemsenin zemini altın ile doldurulmuş üzerindeki yazı nesih hattı ile üstü beç (beyaz) mürekkeple yazılmıştır. Köşebentlerle ortadaki şemse arasındaki bölüm lapist (lacivert) ile doldurulmuş üzerine nebâti motifler zemini boyalı klasik tezhip tekniği ile işlenmiştir.

Köşebentlerin zeminleri altın ile doldurulmuş ve rûmî deseni ile sınırlandırılmıştır. Rûmîler altın ile işlenmiş ve kenarlarına çekilen siyah tahrir ile zeminden ayırt edilmiştir. Köşelerde ayrıca ortadaki lacivert zeminde mevcut olan nebâti grubu helezon sisteminin devamı vardır. Burada teknik zerenderzerdir (Altın üstüne altın). Köşelerde zemin, altınının yanı sıra bordo ile de zenginleştirilmiştir. Dikdörtgen formun alt kısmındaki bölümde yine aynı şekilde tezhiplenmiştir. Bu alanların etrafı zemin açık mavi cedvelle ayrılmış ve üzerine siyah renk ile kurtçuk denilen artı-eksi tezyinat yapılmıştır. Ortada kalan alana Fatiha süresi zemin kâğıdı üzerine siyah mürekkep ile yazılmışırı. Yazının etrafı cedvel sınırlarına kadar beyn-es sûtur formunda altınla doldurulmuştur. Dendanların etrafinda siyah tahrir vardır. Sağında ve solunda dikine uzun iki dikdörtgen pafta bulunur. Bu alanlar orta kısımdan sağda ve solda olmak üzere iki bordo cedvel ile ayrılmıştır. Bordo cedvellerin üzerine beyaz renk ile çintemani motifi işlenmiştir.

Uzun dikdörtgen olan alanlar dendanlı paftalarla ayrılmış, dendanlı alanların içi altın diğer zemin lacivert boyanmıştır. Altın olan zeminin üzerine ortadaki penç motifi merkez sayılarak ters simetri iki helezon yerleştirilmiştir. Bu helezonlar nebâti grubu motiflerden oluşmaktadır. Bu motifler siyah, beyaz ve çeşitli renklerle süslenmiştir. Lacivert kalan kısımlarda ise beyaz çintemani motifi görülür. Sağda ve solda aynı tezyinat uygulanmıştır. Bordo cedveller burada da aynı şekilde yapılmış, sayfanın üst ve alt kısmına doğru uzatılmıştır. Bordo cetveller ile üstte, altta ve yanda bulunan yarım şemseler arasına geniş bir ara suyu uygulanmıştır. İç kısımda beyaz çintemanili bordo cedvel dış kısımda ise üzeri siyah noktalarla süslenmiş turuncu bir iplik bulunmaktadır. Ara suyunun zemini lacivert ile doldurulmuştur. Dendanlı paftalar simetrik olarak birbirini takip eden bir düzende yerleştirilmiş, içine altınla penç ve yapraklardan oluşan ters simetri helezon tasarımı uygulanmışı̧ır.

Sayfanın üstünde, altında ve yanında buluna yarım şemse formundaki süslemeler rûmî motifi ile iki paftaya bölünmüştür. Bu paftaların iç kısmının zemini lacivert, dış kısmının zemini altınla doldurulmuştur. İki pafta içinde birbirini takip eden helezonlar hatâyi, yaprak ve penç motiflerinden oluşmaktadır. Şemselerin sınırındaki lacivert dendanları yine aynı lacivert ve bordo ile işlenen tığlar takip etmektedir.

\subsection{Duraklar}

Duraklar Kur-ân-1 Kerimlerde ayet aralarını gösterir. Bunun yanı sıra yazının tek düzeliğini giderip gözü dinlendirir (Özen, 2007: 107)

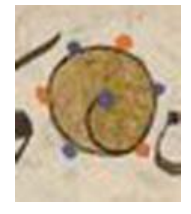

Resim 3: Mushaf'ta Bulunan Duraklarin Görünümü

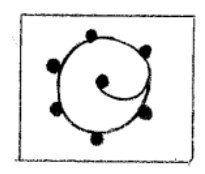

Resim 4: Durak Çizim

İncelemeye aldığımız Mushaf'ın tamamında bir tek çeşit durak kullanılmıştır. Bu durak daire formda tasarlanmıştır (Resim 3). Dairenin içi altın ile doldurulmuştur. Durağın etrafına çekilen siyah tahrir birleşme noktasında içeriye doğru kıvrılarak ucuna mavi bir nokta konulmuştur. Durağın etrafında 
da eşit aralıklarla mavi ve turuncu noktalar mevcuttur.

\subsection{Güller}

Yazma eserlerde, metinde vurgulanmak istenilen yerlerin, sûre başlarını, cüz başlarını belirtmek için sayfaların kenar boşluklarına yapılan ve gülü andıran tezhipli madalyonlara Mushaf gülü denir (Akpınar, 2019: 79). Dönemin tezyini özelliklerine göre farkl1lıklar göstermektedir.

Mushaflarda okumayı kolaylaştıran ibarelerin yazılı olduğu ve genellikle sayfanın kenarında dışa doğru yapılan, değişik formlarda tasarlanan tezyinata 'Gül' denir (Baysal, 2010: 373). Genellikle rozet şeklinde, daire ya da oval formda görülmektedir. İncelediğimiz mushafta 4 farklı şekilde tasarlanmış Aşere, Secde, Cüz ve Hizip gülü bulunmaktadır. Mushafta bulunan diğer güller birbirinin aynı olup tekrar edilmişlerdir.

\subsubsection{Așere Gülü}

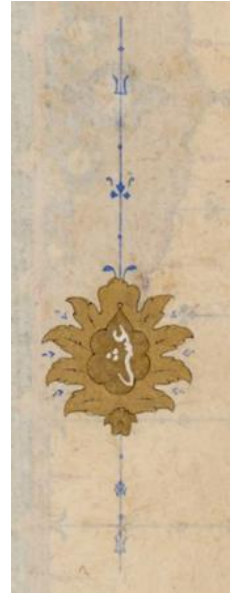

Resim 5: Mushafta Kullanılan Aşere Gülü

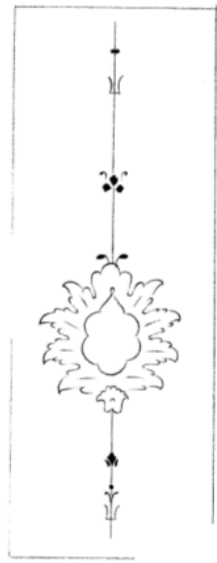

Resim 6: Aşere Gülü Çizim

Arapça'da aşere 10 anlamına gelir ve Kuran-1 ezberleyen veya okuyanlara kolaylık sağlamak amacıyla sûrelerde her on ayette bir yapılır. On ayet kuralı orta ve uzun sûreler için geçerlidir. Eğer buna dikkat edilmeden her on ayette bir aşere gülü tezyin edilmiş olsaydı bir Mushaf' ta toplam 567 aşere gülü yapılmış olurdu.

Mushaf'taki aşere gülleri hatâyi formunda tasarlanmıştır. Zemini altınla doldurulmuş ve kenarlarına siyah tahrir çekilmiştir. Orta kısmı dendanlar ile sınırlandırılmış, içine üstü beç (beyaz) mürekkep ve nesih hattı ile 'Aşere' yazılmıştır. Yukarıya ve aşağıya doğru uzanan lacivert tığlar mevcuttur. 


\subsubsection{Secde Gülü}

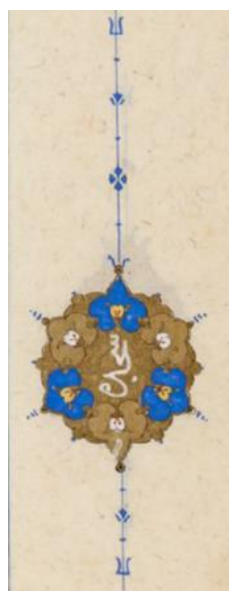

Resim 7: Mushafta Kullanılan Secde Gülü

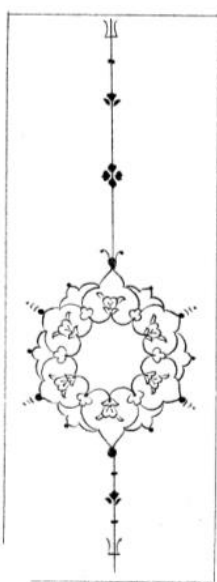

Resim 8: Secde Gülü Çizim

Mushafta secde ayetlerini belirtmek amacıyla bu ayetlerin bulunduğu yerlere yapılan tığlı ya da tığsız tezhipli madalyonlardır. Secde gülleri genellikle oval formda uygulanmıştır. Mushaf’ta bulunan secde gülleri daire formda tasarlanmıştır. Birbirini takip eden helezonlar ortalarda bir çiçekte birleşmiştir. Bir pafta lacivert bir pafta altın ile doldurulmuştur. Ortadaki kısımda altın ile doldurulmuş ve çiçekli kısımdaki altın zeminden parlatılarak ayrılmıştır. Altın ve lacivert paftalar arasında oluşan kısımlara rûmî tepelik yerleştirilmiş ve altınla doldurularak tahrir çekilmiştir. Yukarıya ve aşağıya uzanan lacivert tığlar mevcuttur.

\subsubsection{Cüz Gülü}

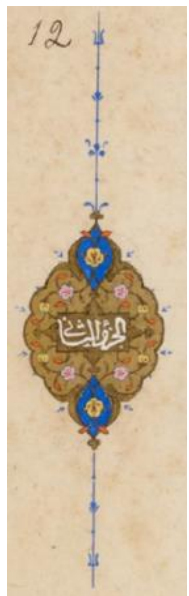

Resim 9: Mushafta Kullanılan Cüz Gülü

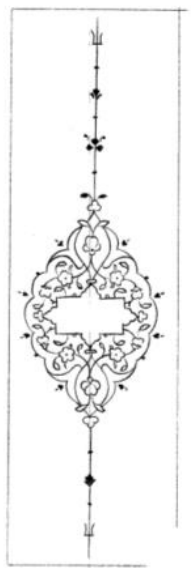

Resim 10: Cüz Gülü Çizim

Mushaflarla ilgili uygulamada; her bir bölümün nerede başlayıp nerede bittiğinin, mushafin tamamının veya bölümlerinin harf ve kelime sayısının ne kadar olduğunun tesbit edilmesi için iki, üç, dört, beş, altı, yedi, sekiz ve onlu bölümlere ayrılmıştır. En yaygın bölümleme mushafın otuza bölünmesi şeklinde olmuştur ki bunlardan her birine "cüz" denmiştir (Maşalı, 2006: 245). İncelemeye aldığımız Mushaf'taki cüz gülleri oval formunda tasarlanmıştır. Ortada düz çizgiler ve küçük tepeliklerle oluşturulan dikdörtgen alan içine üstü beç (beyaz) mürekkeple cüz sayısı yazılmıştır. Oval formunu oluşturan rûmîlerin üstte ve altta oluşturdukları paftaların zemini lacivert ile doldurulmuştur. Orta kısımda altın zemin üzerine altın ve renklerle helezonik olarak tasarlanmış nebâti motifler uygulanmıştır. Altının parlak ve mat kullanılması ile farklılık elde edilmiştir. Yukarıya ve aşağıya doğru 
uzanan lacivert tığlar kullanılmıştır.

\subsubsection{Hizip Gülü}

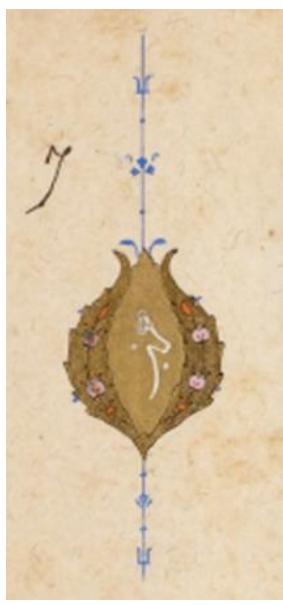

Resim 11: Mushafta Kullanılan Hizip Gülü

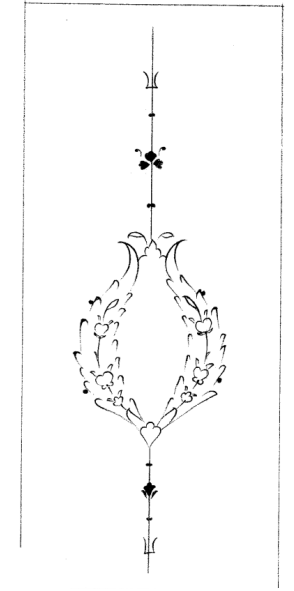

Resim 12: Hizip Gülü Çizim

Cüzler beşerli sayfalar halinde dört bölüme ayrılarak bunlardan her biri için "hizb" tabiri kullanılmış, Osmanlı döneminde yazımı ve basımı gerçekleştirilen mushaflarda bu hizbleri belirtmek amaciyla özel işaretler konmuştur (Maşal1, 2006: 245). Mushaf'taki hizip gülleri oval şekilde hatâyi'ye benzeyen bir formda tasarlanmıştır. Sağda ve solda oval formu veren ve yukarıya doğru daralan yapraklar simetrik olarak kullanılmıştır. Zemini altınla doldurulan yaprakların etrafına siyah tahrir çekilmiş içine küçük goncagüller ve yapraklar yerleştirilmiştir. Ortada kalan kısım altınla doldurulmuş ve içine üstü beç (beyaz) mürekkep ile 'hizip' yazılmıştır. Yukarıda ve altta lacivert tığlar mevcuttur.

\subsection{Sûre Bașları}

Sûre başları Kurân-1 Kerimlerde sûrenin isminin yazılı olduğu genellikle dikdörtgen formda olan tezhipli bölümlerdir. İncelemeye aldığımız Mushaf'ta birçok şekilde tasarlanmış ve farklı renklerle süslenmiş sûre başları mevcuttur (Baysal, 2010: 373). Birbirinden renk, desen ve kullanılan motifler bakımından ayrılsa da tamamında bir üslup birliği mevcuttur. Benzer özellikler taşıyan sûre başları, genellikle dendanlarla ve beyn-es sûtur tekniğiyle paftalanmıştır. Sûrelerin isimlerinin uzunluğuna göre dendanlı paftalar uzatılıp kısaltılmıştır. Sûre isimleri zemin üzerine siyah mürekkeple ya da altın üzerine üstü beç (beyaz)mürekkeple yazılmıştır.

Sûre başlarının zemini bazılarında rûmî bazılarında yaprak bazılarında ise dendanlarla paftalanmıştır. Tezyin edildiği dönemin bütün ince teknik ve motif detaylarını taşıyan mushaf'ın sûre başlarında bütün detaylarıyla çok zarif bir tezyinat mevcuttur. Zeminlerin lacivert olduğu alanların üstü altınla ya da renkle, zeminlerin altın olduğu alanların üstü ise renklerle, siyah tahrirlerle ve parlak altınlarla tezhiplenmiştir. Kullanılan çiçekler, rûmîler ve yapraklar dönemin özelliklerini yansıtmaktadır. Dikdörtgen formda olan sûre başlarının tamamının etrafı cedvellerle sınırlandırılmıştır. $\mathrm{Bu}$ cedvellerde lacivert, altın, bordo, mavi, açık mavi, açık yeşil ve turuncu renkler kullanılmıştır. Cedvellerin zemin renklerinin üstüne çintemâni, nokta ve artı (+) - eksi (-) kurtçuk tezyin edilmiştir. Sûre başlarının tezyinat özelliklerini benzerlik bakımından sınıflandırdığımızda yedi farklı çeşit bulunmaktadir. 

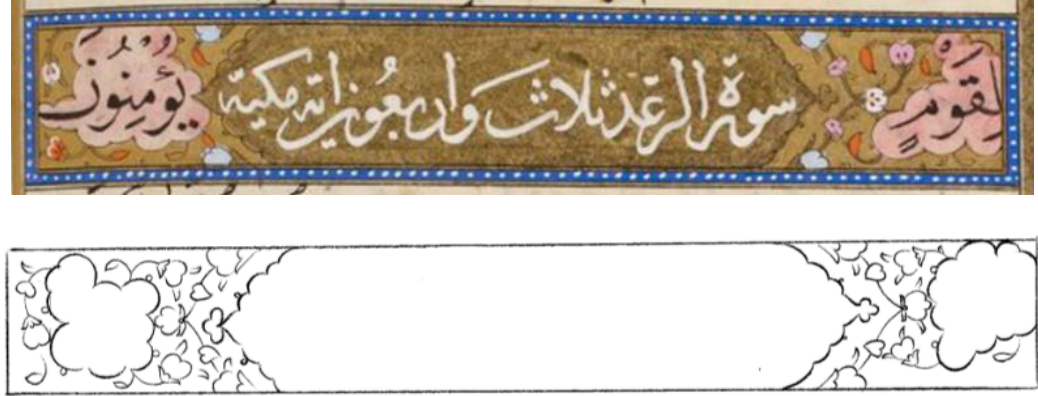

Resim 13: Mushafta Bulunan 1. Çeşit Sûrebaşı Detay Görünümü ve Çizimi

Bunlardan birincisi, sûre isminin etrafının dendanlarla paftalandığ çeşitlerdir. Bu çeşit sûre başlarında zeminde sıvama altın kullanılmıştır. Köşelerde yine dendanlı serbest paftalar mevcuttur. $\mathrm{Bu}$ paftaların içine sûre ile ilgili ibareler yazılmıştır. Sıvama altın olan orta kısımın üzerine sûre ismi üstü beç (beyaz) mürekkep ile yazılıdır. Dendanlı paftaların arasında kalan kısımların üzerine nebâti motifler helezonik bir biçimde altın ve renklerle işlenmiştir. Bu çeşit, sûre başlarında en çok kullanılan tekniktir. Mushafta bu kompozisyon tekniği ile yapılan sûrebaşı tezhiplerinin kullanıldığı sûreler şunlardır; En'am Sûresi, Tevbe Sûresi, Yusuf Sûresi, Ra'd Sûresi, İbrahim Sûresi, Hicr Sûresi, Hâc Sûresi, Mü'minûn Sûresi, Neml Sûresi, Lokman Sûresi, Hucurât Sûresi, Haşr Sûresi, Cumâ Sûresi, Tahrim Sûresi, Kalem Sûresi, Meâric Sûresi, İnfitâr Sûresi, Felâk Sûresi
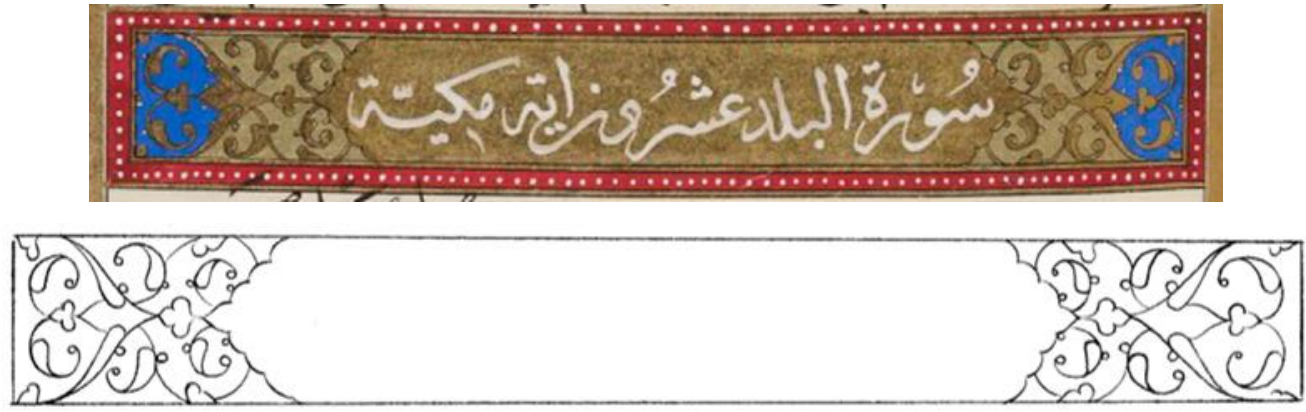

Resim 14: Mushafta Bulunan 2. Çeşit Sûrebaşı Detay Görünümü ve Çizimi

İkinci sûre başı çeşidi, altın rûmîlerle paftalanmış sûre başlarıdır. Bu sûre başlarında zemin sıvama altın ile doldurulmuş ve mat bırakılmıştır. Sûre ismi üzerine üstübeç (beyaz) mürekkep ile yazılmıştır. Rûmî paftalar köşelere doğru uzatılmış, altınla işlenmiş ve parlatılımıştır. Sûre başları ve rûmî paftalar arasında kalan kısım lacivert ile doldurulmuş, içine altınla çiçek ya da rûmî motifi işlenmiştir. Mushafta bu kompozisyon tekniği ile yapılan sûrebaşı tezhiplerinin kullanıldığı sûreler şunlardır; A'râf Sûresi, Yûnus Sûresi, Nahl Sûresi, Kehf Sûresi, Saf Sûresi, Teğabun Sûresi, Beled Sûresi.

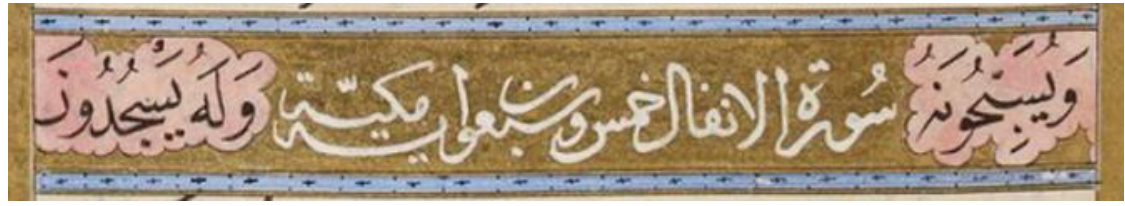

Resim 15: Mushafta Bulunan 3. Çeşit Sûrebaşı Detay Görünümü

Üçüncü sûre başı çeşidi, zeminin tamamen sıvama altın ile doldurulduğu çeşittir. $\mathrm{Bu}$ sûre başlarında sûre ismi üstübeç mürekkeptir. Sûre başlarının sağında ve solunda dendanlı paftalar oluşturulmuş ve zemin rengi üzerine siyah mürekkeple sûre ile ilgili ibareler yazılmıştır. Mushafta bu kompozisyon tekniği ile yapılan sûrebaşı tezhiplerinin kullanıldığı sûreler şunlardır; Enfâl Sûresi, Enbiya Sûresi, Kasas Sûresi, Mülk Sûresi. 

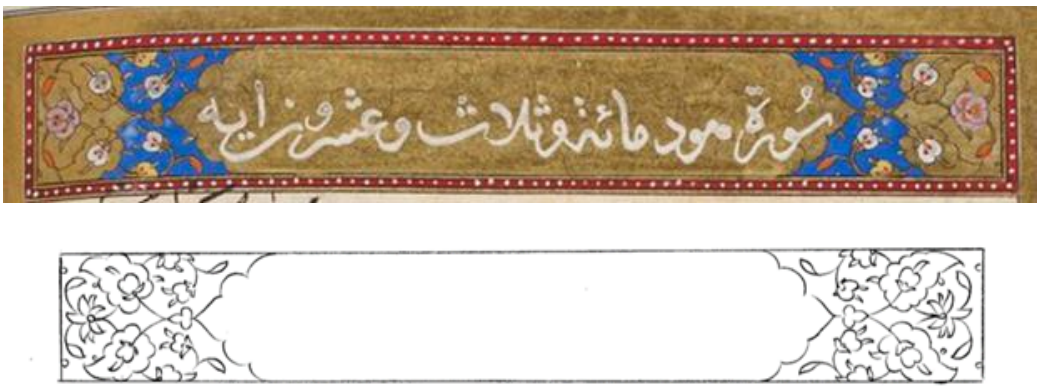

\section{Resim 16: Mushafta Bulunan 4. Çeşit Sûrebaşı Detay Görünümü ve Çizimi}

Dördüncü sûre başı çeşidi ise, çeşitli yapraklarla paftaların oluşturulduğu sûre başlarıdır. Bu çeşit sûre başlarında zemin sıvama altın doldurulmuş üzerine sûre ismi üstübeç mürekkep ile yazılmıştır. Köşelere doğru yapraklarla paftalar oluşturuşmuş, orta kısımlar dendanlarla ayrılmıştır. Zeminlerde altın ve lacivert kullanılmış üzerine helezonik nebâti çiçekler işlenmiştir. Mushafta bu kompozisyon tekniği ile yapılan sûrebaşı tezhiplerinin kullanıldığı sûreler şunlardır Hûd Sûresi, Tâhâ Sûresi, Sebe Sûresi, Şûrâ Sûresi, Zariyât Sûresi, Münafikûn Sûresi, Talâk Sûresi, Leyl Sûresi.
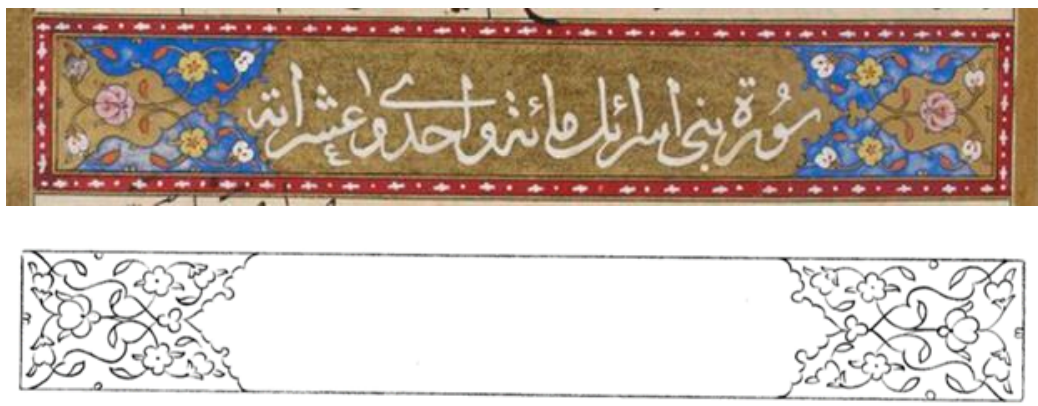

Resim 17: Mushafta Bulunan 5. Çeşit Sûrebaşı Detay Görünümü ve Çizimi

Beşinci sûre başı çeşidi, sadece dendanlarla paftalanmış çeşitlerdir. Bu sûre başlarında orta kısım sıvama altın ile doldurulmuş, üzerine sûre ismi üstü beç (beyaz) mürekkep ile yazılmıştır. Köşelerde kalan dendanlı paftaların zemini kâğıt rengi bırakılmış ve içine siyah mürekkeple sûre ile ilgili ibareler yazılmıştır. Altın paftalar arasında kalan zemin lacivert ile doldurulmuş ve üzerine altın ve farklı renkler kullanılarak nebâti çiçekler işlenmiştir. Mushafta bu kompozisyon tekniği ile yapılan sûrebaşı tezhiplerinin kullanıldığı sûreler şunlardır; İsrâ Sûresi, Meryem Sûresi, Ankebût Sûresi, Saffât Sûresi, Muhammed Sûresi, Hadîd Sûresi.
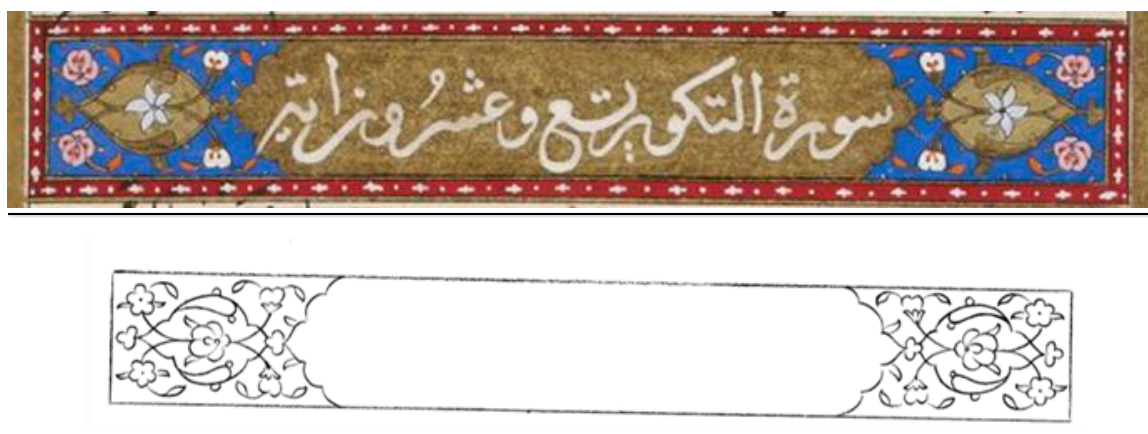

Resim 18: Mushafta Bulunan 6. Çeşit Sûrebaşı Detay Görünümü ve Çizimi

Altıncı çeşit sûre başı çeşidi ise, rûmîlerle ve tepelik motifi ile paftalamaların yapıldı̆̆ı çeşittir. Yazı zemini sıvama altın ile doldurulmuş ve üzerine sûre ismi üstü beç (beyaz) mürekkep ile yazılmıştır. Köşelere doğru rûmîlerle paftalar oluşturulmuş ve altına işlenmiştir. Yazı zeminindeki ve köşelerdeki altın doldurulmuş alanların arası lacivert ile boyanmıştır, üzerine altın ile helezonik şekilde nebâti 
çiçekler işlenmiştir. Köşelerdeki altın zeminler bazı sûre başlarında bordo ile doldurulmuştur. Birinci çeşit sûre başı tekniğinden sonra en çok kullanılan ikinci tekniktir. Mushafta bu kompozisyon tekniği ile yapılan sûrebaşı tezhiplerinin kullanıldığı sûreler şunlardır; Fâtır Sûresi, Yasin Sûresi, Mü'min Sûresi, Kamer Sûresi, Vakıâ Sûresi, Cin Sûresi, Mürselât Sûresi, Nebe' Sûresi, Tekvîr Sûresi, Burûc Sûresi, Şems Sûresi, Tin Sûresi, Nâs Sûresi.
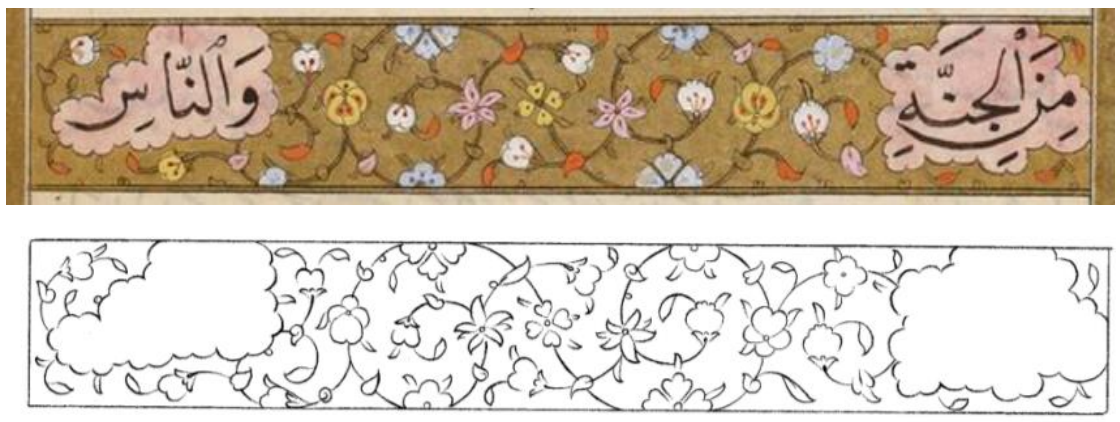

Resim 19: Mushafta Bulunan 7. Çeşit Sûrebaşı Detay Görünümü ve Çizimi

Son olarak tek bir yerde kullanılan sûre başı formunda tezhipli bir bölüm vardır. Burası Kur'an-1 Kerim'in son sûresi olan Nas Sûresi'nin son ayetinin Mushaf'ın sonunda yazıldığı tezyinatlı alandır. Zemini tamamen sıvama altın doldurulmuş, üzeri helezonik nebâti çiçekler kullanılarak tezyin edilmiştir. Sağda ve solda Nas sûresinin son ayetinin yazılı olduğu alanlar dendanlı paftalarla bölünmüştür. Buradaki ayet-i kerime (Min-el cinnet-i vennâs) kâğıt zemini üzerine siyahla yazılmıştır.

\section{DEĞERLENDIRME VE SONUÇ}

Fransız Milli Kütüphanesi’nde bulunan ve Gallica dijital kütüphane aracılığıyla ulaşım sağlayabildiğimiz Kurân-1 Kerim gerek desen gerek renk ve kompozisyon bakımından değerlendirildiğinde 16.yy. Osmanlı dönemine benzemektedir. Kütüphane kayıtlarında da 16. yüzyıl ibaresi bulunan mushaf'ın ketebe sayfası bulunmadığı için hat ve tezhip sanatkârlarının isimlerine ulaşılamamıştır. Estetik ve dairesel hatlarını taşıyan eser, bozulmadan korunarak geçmişten bugüne kadar gelebilmiştir. Tezyinat açısından incelemeye aldığımız Kurân-1 Kerim'in tezhipli bütün bölümlerinde genel bir uyum ve ahenk vardır. Hem motiflerin tasarlanışı hem de işçilikteki titizlik ve ustalık, Mushaf'1 tezhipleyen sanatkârın, sanatında ne kadar mahir ve kabiliyetli olduğunu göstermektedir.

Mushaf özellikle form açısından Klasik dönemde kullanılan kubbeli bir formda oluşturulmuştur. İncelediğimiz mushafın envanter ve ketebe kaydı bulunmasa da Süleymaniye Ktp, Ayosofya nr 3296, Şehzade Korkut Mushafı SSM. Nr.279, Şah Mahmud Nişâburi Albümü IÜK.F.1426 ve SSM. Nr. 56 da kayıtlı olan 16. Yüzyıl yazma eserlerinin serlevha formlarılla temel aynı özellikleri taşıması bakımından bu tarih ile değerlendirmek mümkündür. Şah Mahmud Nişâburi IÜK.F.1426 numaralı mushafın özellikle üst alınlık kısmında ve yazı alanlarının kenar kısımlarında bulunan alanlarda uygulanmış bahar dalı motiflerinden ve SSM.Nr.56'da kayıtlı olan mushafın yine alınlık kısımlarının kenar kısımlarında bulunan bulut motifleri Nakkaş Karamemi üslubu özelliklerindendir. Yine Süleymaniye Ktp, Ayosofya nr 3296 envanter numaralı Tabakātü'l-memâlik ve derecâtü'l-mesâlik isimli yazma eserin Kanuni döneminde yapılmış olması ve SSM. Nr. 279 numaralı eserin de 16. Yüzyıla tarihlenmesi incelediğimiz mushafla benzer özellikler göstermesi bakımından eserlerin çağdaş dönemlerde tezhiplenmiş olması ihtimalini arttırmaktadir. 


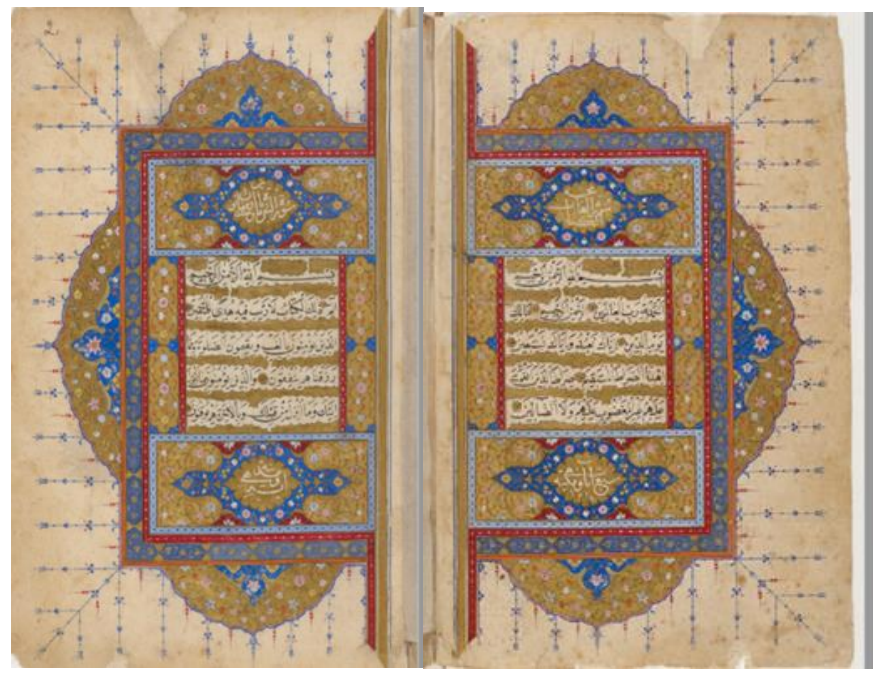

Resim 20: Gallica Digital Library Arabe 482 Numaralı Mushaf

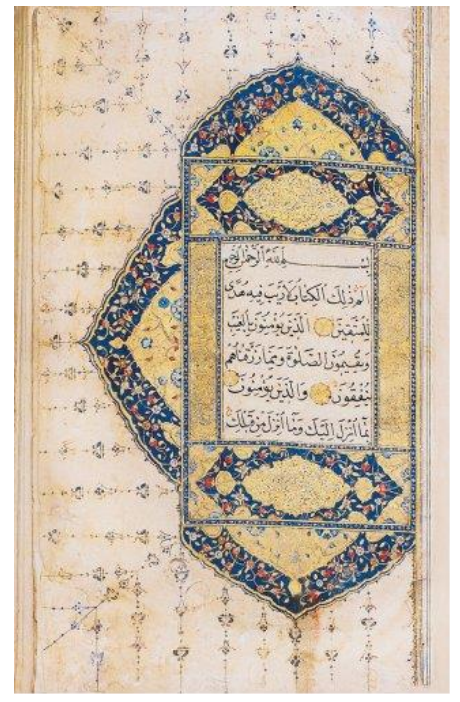

Resim 21: Şehzade Korkut Mushafi SSM. Nr. 279

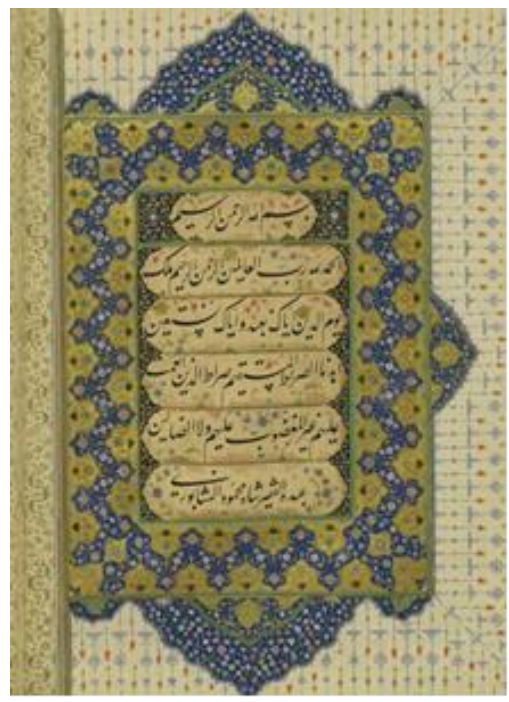

Resim 23: Şah Nişâburi Albümü İÜK. F. 1426

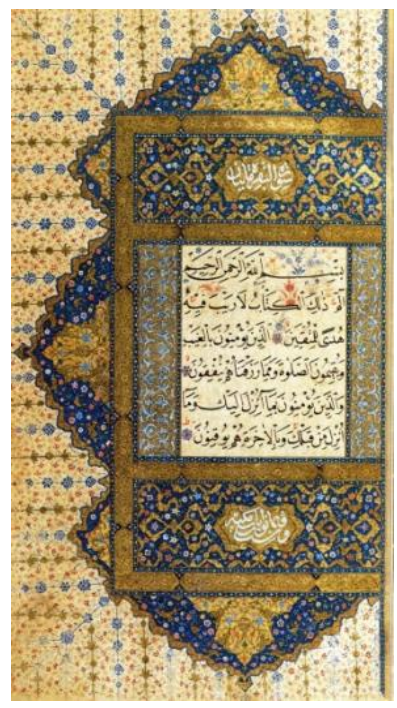

Resim 22: SSM. Nr. 56

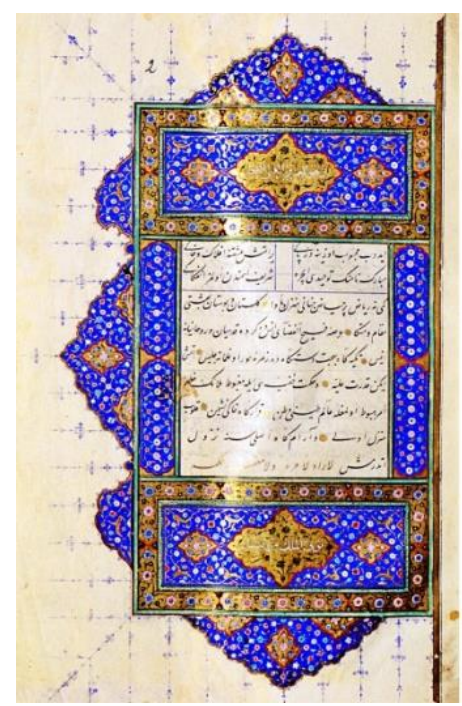

Resim 24: Celalzade Mustafa Çelebi

Süleymaniye Ktp., Ayosofya Nr. 3296 
Mushaf'ın durakları incelendiğinde, bütün ayet aralarında, Kur'ân-1 Kerim'in tamamında tek bir çeşit durak kullanıldığ 1 tesbit edilmiştir. Daire formdaki bu durak, Mushaf'ın tamamında aynı formda ve renkte kullanılmıştır.

Mushaf' In güllerini incelediğimizde, tamamında dört farklı gül tesbit edilmiştir. Bu güller; Aşr, Secde, Cüz ve Hizb gülleridir. dört faklı formda ve renkte tasarlanıp işlenen güller, gerekli oldukları yerlerde tekraren kullanılmıştır. Çalışmanın içerisinde bu güllerin tezyini özellikleri detaylı bir şekilde incelenmiştir.

Tığlarda kullanılan üslup yine 16. yüzyılda görülen üslup özelliklerini taşımaktadır. Verilen örneklerdeki eserlerin tığları incelendiğinde klasik dönem üslubunda tezyin edildikleri, genel olarak lacivert rengin kullanıldığı görülmektedir. Yer yer ana rengin arasına lal mürekkep ile kırmızı renkler de eklenmiştir. Bu uygulama incelemeye aldığımız eser ve diğer Kanuni dönemi yapılmış eserler de de yapılmış olması eser tarihinin saptanması bakımından önemlidir.

Sûre başları ise çok farklı formlarda ve renklerde tasarlanıp tezyin edilmiştir. İncelemeye aldığımız sûre başlarını, form, desen, renk ve teknik olarak sınıflandırdığımızda, birbirine çok yakın benzerlik gösteren altı farklı çeşit tespit edilmiştir. Birbirinden farklı bu altı çeşit sûre başı tezyinatını sınıflandırırken, tasarım, form, renk, teknik ve paftalama şekillerine, kullanılan motiflere dikkat edilmiştir. Yapılan incelemeler sonucunda ortaya çıkan sûre başı çeşitleri teorik açılamalarla ve çizimlerle tarif edilmiştir.

Son olarak, sûre başı formunda olan fakat içinde sûre ismi yazmayan tezyinatlı bir alan Kur'ân-1 Kerim'in son sayfasında dikkati çekmiştir. Burada Kur'ân-1 Kerim'in son sûresi olan "Nas sûresi”nin son ayeti yazmaktadır. Tezyini açıdan diğer sûre başlarından tamamen farklı olup, sadece bir kere Mushaf'in sonunda kullanılmıştır.

Mushaf'ın tamamındaki tezyinatlı kısımlar, en ince detaylarına kadar net bir şekilde görülmektedir. Çok iyi muhafaza edilip, dijital ortama aktarıldığı da tesbitlerimiz arasındadır. Ketebe sayfası bulunmayan eserin Hat ve Tezhip san'atkârlarının isimlerine malesef ulaşılamamıştır.

Kültür mirasımız içinde oldukça büyük bir öneme sahip olan yazma eserler bünyesinde hiç şüphesiz biz Müslümanlar için en kıymetlileri Kurân-1 Kerimlerdir. Amacımız gün yüzüne çıkmamış bu şaheserleri ilmimiz ve bilgimiz yettiğince değerlendirip, elde ettiğimiz sonuçları bir sonraki nesile aktarabilmektir. 


\section{KAYNAKÇA}

Akpınar., A, B. (2019). İstanbul Üniversitesi Kütüphanesi'nde bulunan 18. yy'da Yedikuleli Seyyid Abdullah tarafindan yazılmış olan Kur'an-ı Kerim'in tezyinat bakımından incelenmesi, (Yayımlanmamış Yüksek Lisans Tezi), Mimar Sinan Üniversitesi Geleneksel Türk Sanatları Anasanat Dalı Tezhip Programı.

Aş1c1., S. (2009). Kitap dostu bir sultan: fatih, hat ve tezhip sanatı. Kültür ve Turizm Bakanlığ1 Yayınları.

Atasoy., N. (2016). Muhibbi divanı. Masa Yayınları.

Baysal., A, F. (2010). Mushaf tezyinatının tarihi içindeki gelişimi. Marife, 10(3), 365-386.

Baysal., A. \& Sayın., A. (2019). Restorasyon sonrası kubbe-i hadrâ kalem işleri üzerine değerlendirme, Istem, (33), 39-64. DOI: 10.31591/istem.550810

Celasin., A, T. (2013). XVI. yüzyıl mushaf güllerinin Süleymaniye Kütüphanesi’nde bulunan üç Kur'an-1 Kerim kapsamında incelenmesi. Süleyman Demirel Üniversitesi Sosyal Bilimler Enstitüsü Dergisi. (17), 101-117.

Derman., F. Ç. (2002). Türk tezhip sanatının asırlar içinde değişimi, Türkler. 12, 289-299.

Duran., G. (2009). 18. yüzyll tezhip sanatı, hat ve tezhip sanatı. Kültür ve Turizm Bakanlığı Yayınları.

Gülnur., D. (2012). Tezhip sanatının kullanım alanları, TDV İslam Ansiklopedisi. (Cilt.41), TDV İslâm Araştırmaları Merkezi.

Hatipoğlu., O. (2014). Ankara milli kütüphanede bulunan 19. yüzy1la ait Kur'an-1 Kerim'lerde serlevha bezeme örnekleri. Akdeniz Sanat Dergisi, 7(13), 148-161.

Küpeli., G. (2009). Tezhip sanatında yenilik arayışları: II. Bayezid Dönemi, hat ve tezhip sanatı. Kültür ve Turizm Bakanlığı Yayınları.

Maşalı,, M, E. (2006). Mushaf. TDV İslam Ansiklopedisi (Cilt.31, ss.242-248). TDV İslâm Araştırmaları Merkezi.

Mesara., G. (2009). Kanûni Sultan Süleymanın sernakkaşı ve karamemi, hat ve tezhip sanatı. Kültür ve Turizm Bakanlığı Yayınları.

Özen., M. (2007). Tezhip sanatından örnekler. Kişisel Yayınlar.

Özkeçeci., İ. (2007). Türk sanatında tezhip. Yazıgen Yayınevi.

Özönder., H. (2003). Ansiklopedik hat, Tezhip Sanatları Deyim ve Terimleri Sözlüğ̈̈. Sebat Ofset Yayınevi.

Serin., M. (2003). Hat sanatı ve meşhur hattatlar. Kubbealtı Neşriyat.

Serin., M. (2006). Mushaf. TDV İslâm Ansiklopedisi. (Cilt.31, ss.248-254). TDV İslâm Araştırmaları Merkezi.

Üçer., M. (1994). XVI.-XVIII. Yüzyıllarda türk tezhip sanatında ekol olmuş sanatçıların karşılaş̧tırılması. (Yayımlanmamış Sanatta Yeterlilik Tezi), Mimar Sinan Üniversitesi Geleneksel Türk El Sanatları Anasanat Dalı Tezhip Programı. 